\title{
希薄界面活性剤水溶液の単一円柱周りにおける流動特性*
}

\author{
西 村 龍 夫*1, 国次公司*1, 越智 佑 ${ }^{* 2}$ \\ 小 西 健 太 $^{* 2}$, 田之上健一郎*1
}

\section{The Fluid Dynamical Properties of a Dilute Surfactant Solution around a Circular Cylinder}

\author{
Tatsuo NISHIMURA*3, Koji KUNITSUGU, Yusuke OCHI, \\ Kenta KONISHI and Ken-ichiro TANOUE \\ ${ }^{* 3}$ Department of Mechanical Engineering, Yamaguchi University, \\ 2-16-1 Tokiwadai, Ube-shi, Yamaguchi, 755-8611 Japan
}

\begin{abstract}
Influence of adding cationic surfactant (Ethoquard O12) with a consentration of $50 \mathrm{ppm}$ on water flow around a cylinder in a range of Reynolds number $R e_{s}$ between from 64 to 600 was investigated by using LDV and PIV. At $R e_{s}=300$, the flow with the surfactant formed a stagnant zone, which appeared periodically, in front of the cylinder expanding along the axial direction. The period of the appearance was about $120[\mathrm{~s}]$. The periodic flow structure was visualized by the measurements of velocity fluctuation. The development of the stagnant zone in front of the cylinder induced the expansion of a low speed flow area near the side of the cylinder.
\end{abstract}

Key Words : Single Cylinder, Flow Visualization, Surfactant Solution, Shear Induced Structure, Unsteady Flow

\section{1. 辕 言}

一様流中に置かれた円柱周りの流れは, 工学的に重 要であり, 従来から多くの研究がなされている. ニュ 一トン流体の場合, レイノルズ数 Reが 1 末満では流れ は粘性によって支配され，流体は円柱壁面に沿って流 れる. Re>6では円柱後部で流れが円柱壁面から剥離し， 一対の循環渦が形成される. しかし，Re>40になると， 円柱に付着していた循環渦は時間周期的に主流中へ放 出され, カルマン渦列を形成する(1). 渦の放出過程の詳 細な観察は, $R e>180$ の条件では, 渦は 3 次元的な流れ 構造を有するようになり, 流れ場は周期性の崩れた乱 流と見なせる状態を呈することを示している(2).

近年, 粘弾性流体の円柱周りにおける流れの研究が 行われつつあり ${ }^{(3)}{ }^{(6)}$, その中でも特に, 界面活性剂によ る流体抵抗低減効果が注目されている(5)(().この界面活 性剂は対イオンの存在下で棒状ミセルを形成し, さら に，溶液にせん断を加えると，棒状ミセルが互いに絡 み合ったネットワーク構造体(Shear Induced Structure; SIS)を形成する. この SIS が発生すると, 溶液は高粘 度及び粘弾性を呈すようになることが知られている(7) (9).

Bergins ら ${ }^{(5)}$ は, 陽イオン性界面活性剂 (TTAB1000

* 原稿受付 2005 年 11 月 9 日.

*1 正員, 山口大学工学部 (严755-8611 宇部市常盤台 2-16-1).

*2 山口大学工学部.

E-mail : tnishimu@ yamaguchi-u.ac.jp [ppm])と対イオン NaSal を溶解させた $70^{\circ} \mathrm{C}$ の水溶液を 用い, 円柱下流側の流れ場の観察を行った. 円柱の温 度を溶液よりも $1^{\circ} \mathrm{C}$ 程低下させて行ったシュリーレン 法による可視化実験より, 低 $R e$ 数の流れ場は水と似 た挙動をしているが, 300 から 400 の Re 数で流れ場 が変化し，カルマン渦発生の抑制が始まることを見い だした. またこの状態で流れ方向および流れ方向に 垂直な速度変動を計測したところ, 流れ方向の変動速 度は水と比べて増加するのに対し, 流れに垂直な方向 の速度変動は劇的に減少することを示した.これは, SIS が形成された結果生じる効果であるとしている.

ところで過去の研究においては, Bergins らのものに 見られるように円柱下流側の流れ場にのみ注目してお り，上流側における界面活性剂の効果についてはあま り考察されていない.そこで我々は，陽イオン性界面 活性剂(塩化オレイルビスヒドロキシエチルメチルア ンモニウム $50[\mathrm{ppm}]$ )水溶液を用いて，これまで注目さ れてこなかった界面活性剂水溶液の単一円柱の上流側 およひ側面側での流動特性を調べることを本研究の目 的とする.

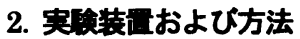

図 1 に実験装置の概略図を示す，試料流体は，整流 装置を通過し縮流ノズルを経てテストセクションに 
流入し, その後, オーバーフローして再びタンクに戻 る循環方式となっている。テストセクションは $80 \times$ $160[\mathrm{~mm}]$ の矩形流路で, 直径 $15[\mathrm{~mm}]$ の円柱をその軸が 流れに垂直になるように設置している，座標系は流れ 方向を $x$ とし, 流れ垂直方向を $y$ とした.

試料流体は, 界面活性剤として塩化オレイルビスヒ ドロキシエチルメチルアンモニウム(商品名:エソカー ド $\mathrm{O} / 12$, ライオン(株製)を質量濃度で $50[\mathrm{ppm}]$, 対イオ ンとしてサリチル酸ナトリウムを $30[\mathrm{ppm}]$ となるよう に溶解させたものを使用し, 溶液温度は $\left.27{ }^{\circ} \mathrm{C}\right]$ とした。 よって, 本研究で用いた界面活性斉水溶液は Bergins らの 用いた TTAB 水溶液と比べると, $1 / 20$ の濃度の希薄溶液 となっている.

円柱周りの流れの可視化には, 蛍光染料法と電解沈 殿法を用いた。 蛍光染料法については, 染料としてロ 一ダミン B 液を用い, 円柱の高さ方向中央付近の側面 に開けた径 $1.0[\mathrm{~mm}]$ の穴から溶液を注入し, アルゴン イオンレーザーを照射してその挙動を観察した。また， 電解沈殿法については, テストセクション上面を陰極, 円柱を陽極として円柱面に導電性塗料を塗布, 電圧を かけてトレーサーを発生, プロジェクターランプによ り白色光を照射して，その挙動を観察した．撮影はテ ストセクション下面よりデジタルビデオカメラによ つて行った。

定量的な計測として，LDV 及び PIVを用いた時間 平均速度の測定を行った. 光散乱粒子には油性の白色 修正液及び $8[\mu \mathrm{m}]$ のポリエチレン粒子を使用した.

流れのレイノルズ数 $R e_{s}$ は, 流路の断面平均流速 $U$ ○と柱直径 $D$ を用いて次のように定義する.

$$
R e_{s}=\frac{\rho D U_{\infty}}{\mu}
$$

本研究で用いた水溶液は $50[\mathrm{ppm}]$ の希薄溶液であるの で, 密度 $\rho$ と粘度 $\mu$ には溶媒である水の值を用いた。

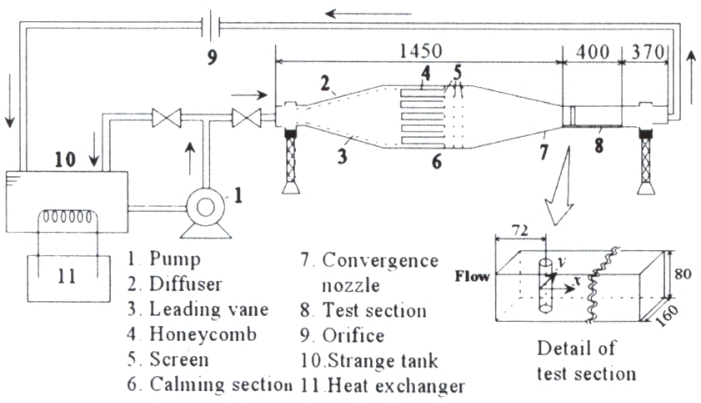

Fig.1 Experimental apparatus.

\section{3. 実験結果および考察}

図 2 に, 各 $R e_{s}$ 数におうる水及び界面活性剂水溶液の円 柱下流側の流れ場を蛍光染料法によって可視化した結果 を示寸. 水の場合, $R e_{s}=179$ ではカルマン渦列が観察され るが, $R e_{s}$ 数が増加するにつれて渦列の輪郭は崩れていき, $R e_{s}=600$ では, 後流は乱れた状態になっている. 一方, 界 面活性斉水溶液の場合, $R e_{s}=179$ では水の場合に見られた カルマン渦が見られず, $R e_{s}=300$ においては, 水に比べて 円柱後流の乱れが抑制され，後流の染料の幅が縮小して いるのが確認できる. この傾向は $R e_{s}^{=} 600$ ではより顕著 であり,これらは, Bergins ら汭蕔告した TTAB 溶液の 円柱周りの流れにおけるカルマン渦の抑制現象に類似 している.

$R e_{s}$

179
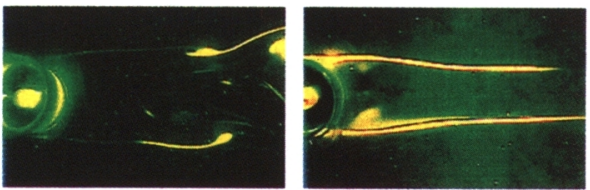

300
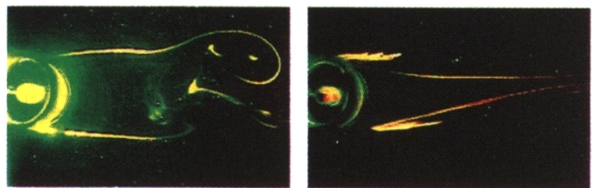

600

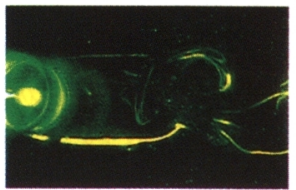

Water

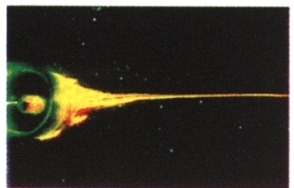

Surfactant
Fig.2 Effect of Reynolds number on the wake region behind a single cylinder $\quad(D=15[\mathrm{~mm}])$.

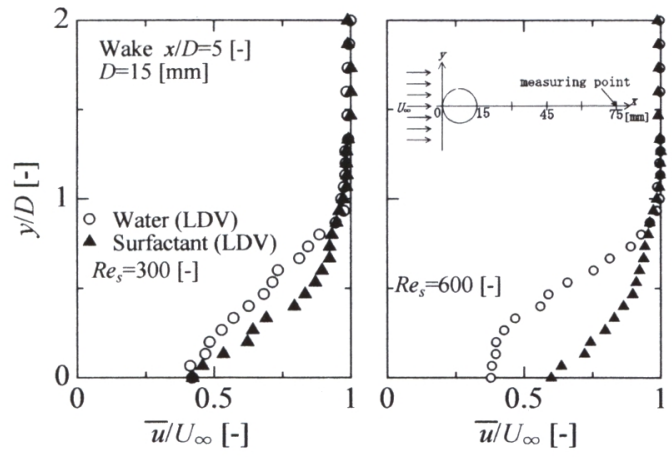

Fig.3 Velocity profile of the wake region behind a single cylinder. 


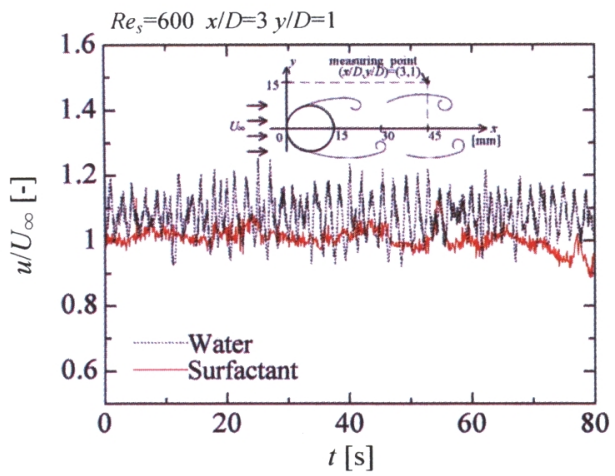

Fig.4 The time signals of velocity fluctuation measured by $\operatorname{LDV}(D=15[\mathrm{~mm}])$.

図 3 は, LDV を用いて円柱後端から下流側に向から て $x / D=5$ の線上における $y$ 方向の時間平均速度分布を 測定した結果を示す，横軸は流れ方向の時間平均速 度 $\bar{u}$ を主流速度 $U_{\infty}$ で, 縦軸は距離 $y$ を円柱直径 $D$ で無次元化したものである. 可視化実験における水と 界面活性剂水溶液の間の著しい違いにも関わらず, $R e_{s}=300$ での時間平均速度の違いはそれほど顕著でな いことがわかる. 一方, $R e_{s}=600$ では可視化において界 面活性剂水溶液の場合に現れた後流の収縮が速度分布 においてもはっきりと認められる.

図 4 は $x / D=3, y / D=1$ の点での速度変動の計測值であ り，水の場合に見られるカルマン渦に起因する周期的 な変動が，界面活性剤水溶液では抑制されていること が示されている. また，PIVによる円柱後流領域の速 度場の計測においても, $R e_{s}^{=125}$ 付近での速度変動は 両者でほとんど変わらないのに対し， $R e_{s}=300 \sim 600$ では劇的に抑制されていることを確認している。これ らの観察結果は，円柱下流側の流れ場が過去に観察さ れた界面活性剤流れの特徴を有していることを示して いる.

ところで, Bergins ら ${ }^{(5)}$ は緒言で述べたように TTAB 溶液の挙動が $R e_{s}=300$ 付近で変化すること, さらにこ の付近の条件では液の挙動が製造日に依存して変化す ることを指摘しておう，これらの結果はこの付近の $R e$, 数が SIS の形成において重要な役割を果たす条件であ ることを示唆している. そして, 本研究における円柱上 流側の流れ場の観察でも $R e_{s}=300$ 付近における特異な 挙動が見いだされた。それは流れ場の長周期変動の 出現である. 図 5 は, 上流部を含む円柱周りにおけ る界面活性剂水溶液の流れの様子を示す. $R e_{s}=64$ で は水と同様に円柱後部に発生していた渦が, $R e$ 数が
Flow direction

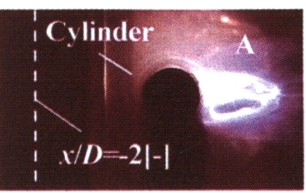

$R e_{s}=64[-]$

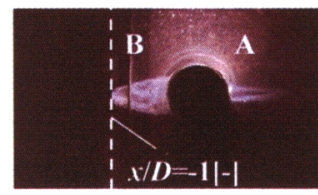

$R e_{s}=300[-]$

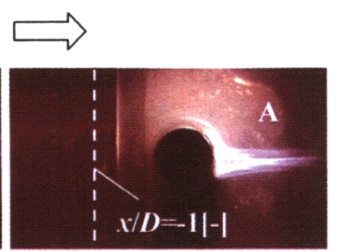

$R e_{s}=179[-]$

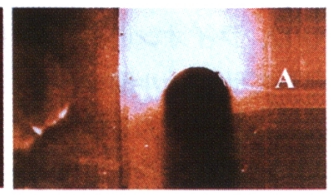

$R e_{s}=600[-]$
Fig.5 The flow behavior in the frontal part of a cylinder

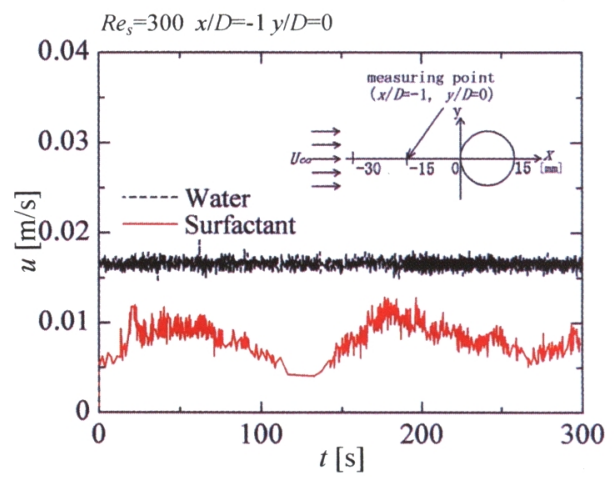

Fig.6 The time signals of velocity fluctuation at the center-line in the frontal part of the cylinder measured by $\operatorname{LDV}(D=15[\mathrm{~mm}])$.

増加した $R e_{s}=179$ では消失している(図中 $\mathrm{A}$ 部分). 代わりに, $R e_{s}=300$ では円柱の上流側によどみ域が生 成されているのが見いだせる(図中 B 部分). 連続し た観測によりこのよどみ領域は分単位の周期で流れ 方向に伸縮することが見いだされた。図中には最も 上流側に伸張した状態を示している.しかしながら， $R e_{s}=600$ では上流側のよどみ域は消滅し, まっすぐに 伸びた後流だけが観察された(図中 A 部分).

図 6 は, $x / D=-1, y / D=0$ の点における速度変動の計測 值であり, 変動の状況をわかりやすくするために規格化 しない速度値を示している. 水の場合には, 1[s] 程度の 周期の微小な変動のみが現れる実質的に定常な流れ場 であるのに対し, 界面活性剂水溶液では微小変動に加え て $120[\mathrm{~s}]$ 程度の周期を有する長周期の変動の出現が示 されている. 測定位置とよどみ領域の関係から, 図 5 に 示した状態が速度が最も減少している時刻に対応す 

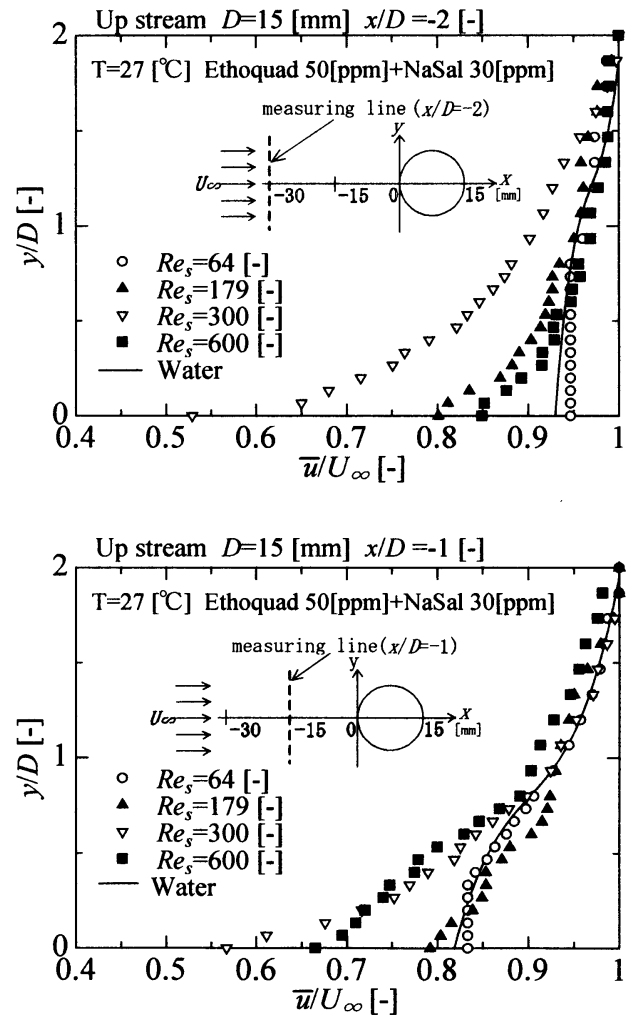

Fig.7 Streamwise velocity profile in the frontal part of the cylinder.

ると見なせる.

$R e_{s}=300$ における長周期変動の効果は時間平均速度 分布にも現れている. 図 7 は, 図 5 中に示した上流側 の $x / D=-2$ および 1 の線上における流れ方向の時間平均 速度分布の測定結果を示す. 水の場合, 速度分布は $R e_{s}$ 数に依存せずほぼ一本にまとまる一方で, 界面活性剤 水溶液では速度分布は $R e_{s}$ 数に強く依存している. 低 $R e_{s}$ 数では, 水の場合と類似した分布を示すが, $R e_{s}$ 数 の増大とともに中心付近の速度に大きな減衰が生じて おり，これは，特に $\operatorname{Re}_{s}=300$ で顕著である. とりわけ, $x / D=-2$ と-1 の間の比較より, $R e_{s}=300$ では他の条件よ りも減衰の生じる領域が拡大していることが見出され， 長周期変動の影響を受けていることがわかる.

円柱周りの粘弾性流体の流れにおいて上流側に出 現するよどみ領域については，過去にいくつかの報告 がある. Ultman ら ${ }^{(10)}$ は, ポリマーCMC-7H $1.7 \%$ 溶解 させた希薄溶液を用いて 0.0002 と非常に低い $R e_{s}$ 数で 単一円柱周りの流れの可視化を行い, 本研究と類似し た円柱上流側のよどみ域の発現を確認した.さらに, オセーン近似に Maxwell の粘弾性モデルに基づく構成 方程式を組み合わせた解析が. 実験の流れをよく再現
することを示した. 薄井 ${ }^{(11)}$ はナビエーストークス方程 式に Maxwell モデルを適用した数值シミュレーション を行い, $R e_{s}=1$ の条件で上流側でよどみ域の存在を示す 流線を得た. Manero と Mena ${ }^{(12)}$ は, ポリアクリルアミ ドとグリコールの水溶液を用いた低 $R e_{s}$ 数の流れの可 視化実験を行った結果, 液の緩和時間が長くなる条件 で上流側によどみ域が出現しやすくなる傾向があるこ とを指摘した. また, 小方ら ${ }^{(13)}$ は, $R e_{s}=20$ の流れに対 して FENE-P 粘弾性モデルを適用した数值シミュレー ションを用いて, エソカード $\mathrm{O} / 12200[\mathrm{ppm}]$ 溶液に対す る可視化実験で得られた円柱前方から側面にかけての よどみ領域の発達の再現に成功したことを報告してい る. これらの結果は上流側のよどみ域の発現は界面活 性阂水溶液の粘弾性に起因することを予想させる. し かし，上述の低 $R e_{s}$ 数域に対する研究ではよどみ領域 は定常的に存在しており, 本研究でみられたような動 的な挙動は示されていない.

Liu と Pine ${ }^{(8)}$ は陽イオン性界面活性剤 CTAB と対イオ ン NaSal をそれぞれ150[ppm]の濃度で溶解させた希薄 溶液の円筒クエット流の観察において, 円筒間のせん断 速度を増大させていくと, 静止円筒面上から SIS によって 構成されると思われる高粘度流体の指状構造が生成され， 分単位の周期で伸縮を繰り返す非定常な挙動を示すこと を見いだした. 彼らはまた, 指状構造の伸縮周期がせん断 力の増减の周期に対応することを指摘している. 本研究で 見いだされたよどみ領域の挙動は彼らが見いだした指状 構造の挙動と類以した特徴を有しており, Bergins らが指 摘した水溶液の挙動を考慮すると，両者はせん断による SIS の形成と変化という面で関係を有していることが予 想される. しかしながら Liu と Pine が指摘するようにこ の挙動は界面活性剂水溶液による抵抗操作の原理と密 接な関係があり，これは現時点では解明されていない 問題である.

先に述べたように，円柱下流側の流れ場ではカルマ ン渦の抑制とともに流れの変動特性が変化することが見 出されている. 一方, 円柱上流部においても $R e_{s}=300$ でみ られたような非定常挙動が生じている. そこで, 円柱 上流側で PIV 計測に基づく変動解析を行い，変動特性 の変化を調べた，図 8 は, PIV を用いて得られた各 $R e_{s}$ 数における変動エネルギ一分布を, 主流の運動エネル ギーで無次元化した結果である. 測定条件としては, 最も長周期の変動が予想される $R_{s}=300$ に対応して, $x / D=-1.5 \sim 0, y / D=-0.5 \sim 0.8$ の範囲を $2[\mathrm{~s}]$ 間隔で測定した 60 枚のベクトル画像から変動エネルギーを算出した. なお, 変動エネルギーの各成分は次のように定義した. 


$$
\begin{aligned}
& \overline{u^{\prime 2}}=\left[\sqrt{\frac{1}{n} \sum(u-\bar{u})^{2}}\right]^{2} \\
& \overline{v^{\prime 2}}=\left[\sqrt{\frac{1}{n} \sum(v-\bar{v})^{2}}\right]^{2}
\end{aligned}
$$

$R e_{s}=300$ においては, 変動エネルギー分布に組織的 な構造がみとめられ，流れ場の変動の規則性を反映し ている.ここで注意すべきは $R e_{s}$ 数の低い $R e_{s}=64$ およ び 179 においても変動エネルギーの規則的な分布が見 られることでありこれらの条件でも微小な周期的変 動が生じていることが示唆される. 一方, $R e_{s}=600$ で はエネルギーの顕著な分布構造は見られなくなり, 流 れ場が周期的に変動する構造を持たない, 均質に乱れ た状態に遷移していると判断される. しかしながら， $R e_{s}=179$ と 300 で見られるように, 変動エネルギーの 分布には特に円柱近傍において強い左右非対称性が 存在している. Bergins らの速度変動の計測結果(5)は, 円 柱の上流側では下流側とは反対に, 流れに垂直な方向の 変動が増大寸ることを示しており, 本研究においても 円柱近傍において図 6 に示した $x$ 方向の変動よりもさ らに長周期の $y$ 方向の変動が存在していることが予想 される. そこで, 図 8 に示した計測範囲内における各 $R e_{s}$ 数での変動エネルギーの最大值を主流の運動エネ ルギーで無次元化した值を変動強度の指標として採

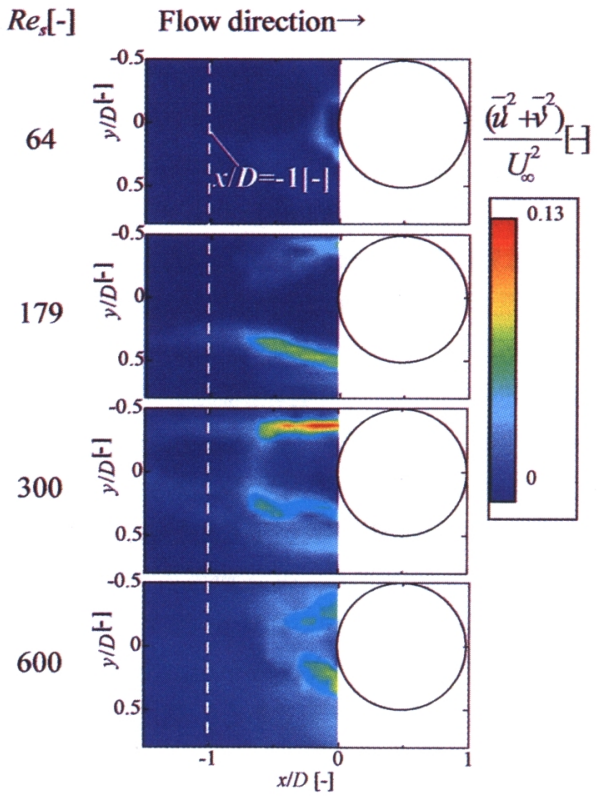

Fig.8 Fluctuation energy in the upstream side of the cylinder for the surfactant solution

$(D=15[\mathrm{~mm}], 60[\mu \mathrm{m} /$ pixel $])$.

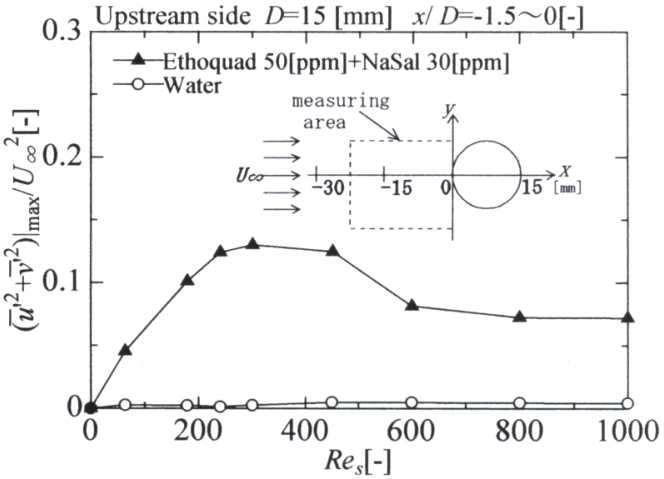

Fig.9 Maximum of fluctuation energy in the frontal part of the cylinder $(\mathrm{D}=15[\mathrm{~mm}])$.

用し, 流れ場の変化を評価した. 図9にその結果を示 す.これより，よどみ域の周期的変動が観察された $R e_{s}$ 数域では変動強度が増大することが確認できる.なお, $R e_{s}$ 数を増加させると変動成分の最大值は減少するが, これは図 8 の $R e_{s}=600$ の分布図からわかるように, 流 れ場が均質化した結果, 変動がピークを示文領域が存 在しなくなるためである.

最後に, 円柱周りの流れ場を把握するため, 円柱側 壁近傍の $x$ 方向速度測定圭行った. 図10に各R $e_{s}$ 数での

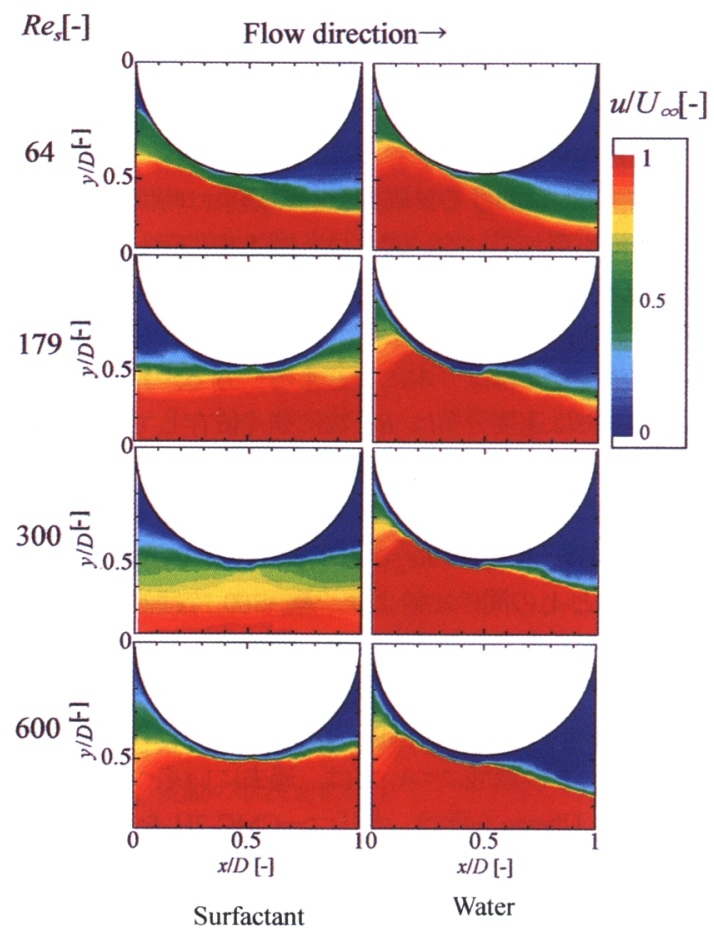

Fig.10 Streamwise velocity profiles near the cylinder $(\mathrm{D}=15[\mathrm{~mm}])$. 
瞬間の速度分布の測定結果を示す. 陽イオン性界面活 性剤水溶液の場合, $R e_{s}=300$ ではよどみ領域が最大に 伸張した時刻での結果を示し, 顕著な変化の見られな い他の 3 条件では任意の時刻の結果を示している. ま た, 水の場合この部分の流れはほとんど定常であると 見なせるので, 4 条件とも任意の時刻の結果を示して いる. 界面活性剂水溶液の場合, $R e_{s}=64$ では円柱上流 部の流体は断面平均流速の值を示す赤色領域の分布 からわかるように壁面に沿って流れる傾向を示寸.し かし, $R e_{s}$ 数の増加に伴ってくぼみ上流側に周期的な挙 動が発達するとともに赤色領域は円柱から離れてい き, 代わりに, 円柱側面に黄色で示される流れが減速 された低速域が出現することが確認された. この領域 はよどみ域の発達とともに拡大していくが, $R e_{s}>300$ でよどみ域が减少し流れの周期性が失われていくと ともに，この低流速域も減少することが見出された. 一方, 水の場合, 円柱上流部で流体が壁面に沿って流 れようとする傾向は, $R e_{s}$ 数が増大しても維持されてお り, $R e_{s}=300$ と 600 における瞬閒の速度分布には顕著 な違いは見られない.

図 10 で見られたような, 円柱を取り巻く低速域の 出現は, 小方ら ${ }^{(13)}$ の研究においても見いだされている. しかし, 彼らの流れ場は時間変動しておらず, また, 本研究でもこの部分の非定常挙動の詳細な解析は行 わっていない. 本研究で見いだされた円柱上流側の非 定常な挙動が円柱側面, さらには下流側の流れの変化 とどのような関係を持っているかという点について は, 今後さらなる検討が必要である.

\section{4. 結 言}

径が $15[\mathrm{~mm}]$ の単一円柱の上流側および側面側にお ける陽イオン性界面活性剤(Ethoquad O/12;50[ppm] $+\mathrm{NaSal} ; 30[\mathrm{ppm}]$ 水溶液の流動特性を可視化と速度計測 により調べた結果, 以下の知見を得た.

(1) $64<R e_{s}<600$ の範囲で円柱上流を可視化した結果, $R e_{s}=300$ において円柱上流部におけるよどみ域の
顕著な発達が観察された. さらにこのよどみ域は 約 $120[\mathrm{~s}]$ の周期で流れ方向に伸縮していることが 見いだされた。

(2) 円柱上流部の変動エネルギーの分布の変化より, 流れの周期的な変動が $R e_{s}=300$ よりも低い $R e_{s}$ 数に おいて生じていること, また, $R e_{s}$ 数の増大と共 に流れがより乱れた状態に遷移していることが 示唆された.

(3) 円柱上流のよどみ域と周期的な変動の発達に伴 い, 円柱側面で低速流域が拡大することが確認さ れた.

\section{文 献}

(1) Tanekoda, S., The Study of Fluid Mechanics using Flow Visualization (in Japanese), Asakura- Shoten (1988), pp. 90-133.

(2) Williamson, C.H.K., Exp. Thermal Fluid Sci., Vol.12 (1996), pp. 150-168.

(3) Cadot, O. and Lebey, M., Phys. Fluids, Vol.11, No.2 (1999), pp. 494-496.

(4) Cressman, J.R., et al., Phys. Fluids, Vol.13, No.4 (2001), pp. 867-871.

(5) Bergins, C., et al., Exp. Fluids, Vol. 30 (2001), pp. 410417.

(6) Okata, S. and Watanabe, K., Trans. Jpn Soc. Mech. Eng. B, Vol.69, No.687 (2003),pp. 2424-2430.

(7) Hu, Y. and Matthys, E.F., Rheol. Acta, Vol. 34 (1995), pp. 450-460.

(8) Liu, C. and Pine, D. J., Phys. Rev. Lett., Vol. 77, No.10 (1996), pp. 2121-2124.

(9) Saeki, T., et al., J. Soc. Rheology, Japan, Vol. 28, No. 1 (2000), pp. 35-40.

(10) Ultman, J. S. and Denn, M. M., The Chem. Eng. J., 2 (1971), 81-89.

(11) Usui, H., Ph. D. thesis, Kyoto Univ., 2 (1971), pp. 81-89.

(12) Manero, O. and Mena, B., J. Non-Newtonian Fluid Mech., Vol. 9(1981), pp.379-387.

(13) Okata, S., et al., Trans. Jpn Soc. Mech. Eng. B, Vol. 71, No.710 (2005), pp. 2414-2420. 